\title{
HLA-DRA wt Allele
}

National Cancer Institute

\section{Source}

National Cancer Institute. HLA-DRA wt Allele. NCI Thesaurus. Code C101158.

Human HLA-DRA wild-type allele is located in the vicinity of $6 \mathrm{p} 21.3$ and is approximately 5 kb in length. This allele, which encodes HLA class II histocompatibility antigen, DR alpha chain protein, is involved in the mediation of antigen presentation. 